\title{
Normalization of Dream State Police Stigma
}

\author{
Tri Siswanti*, Prof. Dr. Ishomudin, M.Si, Dr. Rinikso Kartono, M.Sc., Dr. Tri Sulistyaningsih, \\ M.Si
}

Doctoral Program in Social Sciences and Political Sciences, University of Muhammadiyah Malang

*Corresponding Author: Tri Siswanti, Doctoral Program in Social Sciences and Political Sciences, University of Muhammadiyah Malang

\begin{abstract}
Building a positive image and reputation in the Indonesian National Police institution is a necessity where for the current National Police the positive image is the main objective to gain public trust. Regarding the image and reputation of the Dream National Police, this institution should have seriously dealt with the problem of imaging. To achieve this, efforts are needed to improve the image of the Dream Police that has been considered less professional through the management of impressions with stigma normalization techniques.

The purpose of this research is to: (1) review and analyze impression management with stigma normalization techniques, (2) describe stigma normalization in order to improve the image in the Dreamland police, and (3) Elaborate all findings in research to recommend suggestions for building good opinions that can be applied in building the Dream State Police Image. Researchers used a qualitative approach with the phenomenological method. The theory used is impression management with the stigma normalization technique in Erving Goffman's perspective. The data collection techniques used in this study are observation, in-depth interviews and documentation. Determination of the subject is the police personnel who carry out the promoter police program as many as 17 people and the term of service is more than seven years. The method of data analysis is done by the procedure of transcribing, bracketing, inventorying important questions, cluster of meaning and essence description.
\end{abstract}

The findings of this study resulted in an impression management technique with the stigma normalization technique for police personnel, namely: (a) dismissal of members who made a serious mistake, (b) religious coaching of Polri personnel who had problems with minor violations, (c) Moved / moved assign Polri personnel who have problems with moderate levels of violation, $(d)$ the leadership must act decisively, $(e)$ the leader must be able to be a good role model, $(f)$ give rewards to personnel who excel and provide appropriate penalties for troubled personnel, $(g$ ) Process troubled police personnel based on the principles of justice and human rights, (f) Conduct a mental revolution by religious formation of troubled police personnel, $(g)$ If minor violations can be given physical punishment such as running six rounds, fifty pushups and others, $(h)$ Improving the welfare of Polri personnel, (i) Providing punishment s essay with the level of violation, ( $j$ ) Lower rank one level lower, and ( $k$ ) Conduct a mental revolution starting from the leadership level.

The conclusions of the results of the research analysis are: In the normalization of stigma, dismissal and demotion for police personnel must be carried out according to the level of violation.

Keywords: Impression management with stigma normalization techniques

\section{INTRODUCTION}

The police force is one of the state institutions in the Republic of Indonesia which has the slogan as a community protector. In addition, the police also provide direct services to the community such as the service of making a Driving License (SIM) and receive public complaints in the form of criminal acts, security and public order. However, according to one community member, the police were not close enough to the community, there was still an invisible distance between the police and the police. In addition, in carrying out their duties, the police are still selfish and often ask for money (Kompas.com, 2009)

To that end, building a positive image and reputation in the Indonesian National Police institution is a necessity where for the National Police at this time a positive image is the main objective to gain public trust. Regarding the image and reputation of the Dream National Police, this institution should have seriously dealt with the problem of imaging. To achieve this, efforts are needed to improve the 
image of the Dream Police that has been deemed unprofessional through impression management. Understanding the image itself is abstract (intangible) and cannot be measured mathematically, but its form can be felt from the results of a good or bad assessment (Ramdhani and Wiwitan, 2018.

The existence of police personnel is very closely related to the community, because the community has the most influence and is the main target in providing services to them. Cases of abuse of authority, ill-treatment, ambiguity in the delivery of information on a case, sexual harassment, unpleasant acts, and the investigation of unfinished cases are depictions of fraud committed by police personnel in the Land of Dreams. So that it will slowly form negative opinions and attitudes of mistrust of the public towards the police institution (Trilaksono, 2015).

The police force is the main pillar in creating security and public order. The opinion formed should be that the police is a role model to be an example and can be relied upon to provide protection and services to the community. When there is an abuse of authority in carrying out duties in the field this will make the community doubtful of the ability of the police to carry out their main duties and functions as protectors and servants of the community.

So complex is the challenge of the current police task, this institution must truly improve in all matters such as in the field of coaching, operational and development. Human resources and facilities and infrastructure. But on the other hand there is still negative access from the implementation of its main tasks in the form of deviations in the behavior of police personnel such as abuse of power (abuse of power), and other misconduct that violates moral, social and religious principles (Ngatiya, 2012).

Based on the results of the Indonesian International Transparency Survey the National Police ranks fifth in the data of government institutions / institutions which are the most highlighted by the public because they often practice KKN, and as a result many achievements of the Police in the field of kamtibmas (security and policing) are covered by various issues or rumors related to the misappropriation of the police. So that the image in the community is very bad, as if there is nothing positive about the image of the police (rappler.com, 2017). According to Goffman (in Sengupta, Banks, Jonas, Miles, \& Smith, 2011; Genberg et al., 2007) defines stigma as a dynamic process of devaluation that significantly discredits an individual in the eyes of other individuals. Stigmatization of police personnel was caused by the police being unable to limit the appearance he was supposed to keep. It was displayed in front of the stage (front region) as if there were traffic violators on the streets that were supposed to be ticketed but instead were invited to negotiations to pay directly and were not given a ticket.

In accordance with Law Number 2 of 2002 concerning the National Police of the Republic of Indonesia, Article 13 paragraph (1) states: "Members of the Indonesian National Police can be dismissed with no respect from the Republic of Indonesia's National Police service for violating the oath / promise of members of the Indonesian Police. Furthermore, in article 1 of Law number 2 of 2002 reads: Police is all matters relating to the functions and institutions of the Police in accordance with statutory regulations.

In accordance with the above Law, the police should protect, protect and serve, not otherwise abuse their authority and commit disgraceful acts that violate moral, social and religious principles such as asking for tribute, complicating, and hurting society. In addition, police personnel should be servants, protectors and protectors of the community by not discriminating between tribes, racial or group religions.

Indeed, not all police personnel cause a bad image in the Dream National Police. Only a few personnel who commit acts violate the Police ethics. This problem requires improvement in all fields starting with senior police officers so that the cause of the bad image of the police in the community must be eliminated. Promoter's motto in the series of policies and development agenda of the National Police to be better, namely professional, modern and trusted. Commitment to realizing the promoter police is an effort to improve the image of the police which so far have been considered to be less professional, less modern and less trusted by the public.

\section{LITERATURE REVIEW}

\subsection{Impression Management Theory}

Impression management (Impression management) developed by Goffman is part of the study of dramaturgy theory. Impression management (impression management) is an attempt by an individual 
to be able to create an impression or perception of himself in public. Impression management is performed on verbal or nonverbal symbols attached to a person. In the research of the image of the National Police examine the extent to which impression management is on the front stage (front region) and the back stage (back stage) of a police personnel in the area of Dream National Police where Goffman has divided into two directions based on the actors who play that role, namely :

\subsubsection{Front Stage (Front Region)}

Discusses the management of impressions played by police personnel actors relating to aspects of appearance and manner.

- The appearance (appearance) of the management of impressions that are reviewed based on the appearance aspect performed by the police personnel actors include the attitude and appearance. What is the attitude and attire of a police officer when the actor is in the front stage that is displayed so that it can create the impression that is desired by the people of the Dreamland and those around them who are part of the performance on the front stage.

- The manner (manner) of impression management is a part that is seen in terms of the style carried out by police personnel actors relating to behavior, attitudes, facial expressions, body language, message content, as well as ways of speaking and language style in ssar is carrying out its role as Police.

\subsubsection{Backstage}

Researchers examined the lives of police actors who are on the road where traffic control and work are done, what is prepared by the police actors reviewed as described above, so they can get involved in the lives of the front region actors. Thus it can be seen that there are significant differences in the process of managing impressions from the lives of back stage actors when compared to the lives of front region actors. There are several important aspects that are part of the backstage life of police actors, including:

- Appearance. Although this research examines the Dream National Police police. But appearance is one aspect that is the focus of research, because the management of impressions on police actors can enable him to use facial makeup on his backstage life for his purposes;

- Clothing functions to create images of the actors who wear them. So that the aspect of clothing worn by police actors is also a matter of study of this study.

- Researcher Attitudes and Behavior. This study focuses on the attitudes and behavior of police actors in the Dream National Police.

- Body Language is one of the identities or characteristics of the actor. As is the case with the Dream State Police police actor, what can be seen is the management of impressions through the movement of his body language.

- Facial Mimic is a form of expression of actors when they interact.

\subsection{Stigma Normalization Theory}

Sociologist Erving Goffman (in Sengupta, Banks, Jonas, Miles, \& Smith, 2011; Genberg et al., 2007) defines stigma as a dynamic process of devaluation that significantly discredits an individual in the eyes of other individuals. Stigma can also be defined as a phenomenon that can affect an individual as a whole (Crocker et al., Jones et al., Link \& Phelan in Major \& O'Brien, 2005). According to Goffman (in Scheid\& Brown, 2010) states that "stigma concept identifies an attribute or a mark residing in the person as something the person possesses" means that the concept of stigma identifies the attribute or sign that is on someone as something that is owned. Stigma also means a phenomenon that occurs when a person is labeled, stereotyped, separated, and discriminated against (Link Phelan in Scheid\& Brown, 2010). Goffman (1963) said that, through passing, covering and techniques of information control, one can reduce the impact of stigma and even avoid stigma. The techniques are used on an ongoing basis with each other in the process of stigmatization. Passing is done by moving from one group to another, for example from groups that have stigma to groups that have less negative stigma than the previous group or even groups that do not have stigma. Passers usually consider themselves (who have a stigma) not part of the stigmatized person Passing is an attempt to disguise / hide the stigma from a group of people who do not know about the stigma or to people who are expected to 
not know the stigma they have.Passing can only be done when the other party does not know or only certain parties who know about the stigma or attributes possessed by someone who might be stigmatized in the community. In this condition, those passing actors try to position themselves in places where they can hide their true identity. The next stage when someone is passing is to control the information related to themselves to their social environment. Controlling information is carried out by people who are stigmatized to avoid in various ways, so people are not aware of their shortcomings and are considered part of a normal group of people, or at least make the attributes that exist in themselves become less stigmatized. Done by limiting the knowledge of others relating to deficiencies that exist in him. The covering is the final stage for those who have the stigma that is known to the public and are willing to accept the stigma as part of him. Covering aims to minimize stigma so that it does not appear clearly so it does not interfere with social interaction between stigma owners and other normal groups.

\section{Method}

This research paradigm uses the social definition paradigm used to understand individual social actions, meaningful individual actions. With the social definition paradigm, it can be studied the process of managing impressions with stigma normalization techniques in improving the image in the Dream National Police. Based on the paradigm of social definition, this study uses a qualitative approach. The reason for using a qualitative approach as opinion of McCusker, K., \& Gunaydin, S. (2015), that the selection of the use of qualitative methods in terms of research objectives is to understand how a community or individuals accept a particular issue. In this case, it is very important for researchers who use qualitative methods to ensure the quality of the research process, because the researcher will interpret the data he has collected. This type of research is phenomenological research. Alfred Schutz (1941) in Philosophy and Phenomenological Research explains that phenomenology is an attempt to understand the meaning of every behavior, speech and interaction in an event or that is associated with a particular situation as a condition for social existence.The research location was determined purposively in the Dream Police. Researchers used purposive techniques in order to obtain valid data and information. Data collection in this study uses several techniques, namely observation, interviews and documentation. These three techniques are carried out simultaneously in accordance with the needs of research data in order to obtain valid and reliable data. Researchers used the interactive and comparative model of Data Analysis techniques from Miles and Huberman (1992). This technique is done by comparing the results of research with the results of previous studies and using the validity test or the validity of the data according to Creswell (2010).

\section{Results}

The findings of research on impression management with the stigma normalization technique are: (a) dismissal of members who make a grave mistake, (b) Lowering the rank to a lower level, (c) Transferring / assigning Polri personnel with problems with moderate level of violation, (d) The leader must act decisively, (e) The leader must be able to be a good role model, (f) Give awards to outstanding personnel and provide appropriate penalties for troubled personnel, (g) Process troubled Polri personnel based on principles justice and human rights, (f) Conducting a mental revolution by religious formation of troubled police personnel, ( $g$ ) If minor violations can be given physical punishment such as running for six laps, pushup fifty times and others, (h) Improving the welfare of personnel Polri, (i) Give punishment according to the level of violation, (j) religious guidance for per sonel of the National Police who have problems with the level of minor violations, and (k) Conduct a mental revolution starting from the leadership level.

\section{CONCLUSiONS}

This researcher studies and analyzes impression management with stigma normalization techniques using dramaturgy as the impact of stigma using the promoter police program. By using a qualitative research design and phenomenological approach. Phenomenology research explains and reveals the management of impressions and experiences based on the consciousness that occurs. Associated with dramaturgy theory and techniques to reduce / eliminate stigma according to Erving Goffman.

From the above research findings it can be concluded that: "In the normalization of stigma, dismissal and demotions must be made for police personnel according to the level of violation". 


\section{RECOMMENDATIONS}

Based on research on impression management with stigma normalization techniques can be recommended are:

\section{- For Polri Institutions}

$>$ In managing impression, it takes a strong moral commitment from the leadership because the leadership commitment makes a big contribution in changing the mentality of police personnel members because the police adheres to a hierarchical system so that anyone who is subordinate leader must be loyal and obedient. Subordinates must submit and subordinates must submit and fear.

> Police personnel are subject to the applicable hierarchy and certainly have a working foundation, professional code of ethics and discipline in accordance with applicable regulations in the Police Institution.

$>$ Conducting mental revolution continuously and continuously so that attitude, good ethics are embedded and can be applied in everyday life.

$>$ Conduct evaluation and monitoring regularly and continuously to improve the professionalism of police personnel and improve the quality of services by using Science Technology and the media as a means of supporting the successful implementation of the task.

\section{- For Police Personnel}

It is hoped that by managing impressions and techniques to reduce stigma, police personnel can have a strong commitment to maintaining the quality of public services and police personnel can work professionally as law enforcement officers and guards of public order which cannot be carried out with a bad mental attitude, so that each police personnel will realize that the image of the institution must be carefully guarded.

\section{- For the Community}

The community needs to care and understand the police were born because of the existence of the community, and the community needs the presence of the police in maintaining order, security and order of the community itself. In maintaining Kamtibmas the Police will succeed if there is community participation. Therefore, the community must also be able to position themselves as police for themselves, so that an emphasis is needed on the presence of police officers in the community at all times and places in order to increase community discipline and compliance.

\section{REFERENCES}

[1] Arief, BardaNawawi. (1998). Some Aspects of the Policy on Recognition and Development of Criminal Law. Bandung: Citra AdityaBakti.

[2] Arief, Effect. (2018). A year of silent reform in the Indonesian National Police Kitchen. Jakarta: Creative Diandra.

[3] Arifin, Anwar. (2014). Imaging Politics. Yogyakarta: Graha Science.

[4] Bungin, Burhan. (2001). Qualitative Research Methodology. Jakarta: PT Raja GrapindoPersada.

[5] Gerungan, W. A. (1996). Social Psychology. Bandung: Eresco.

[6] Goffman, Erving. (1959). The Presentation of Self in Everyday Life. United States of America: Doubleday Anchor Books.

[7] Haryamawan, RMA. (1986). Dramaturgy. Bandung: PT RemajaRosdakarya.

[8] Krippendorf, Klaus. (1993). Content Analysis: Introduction to Theory and Methodology. Jakarta: PT. Raja GrafindoPresada.

[9] Kunarto. 2001. POLRI Organizational Behavior. Jakarta: CiptaManunggal.

[10] Kuswarno, Engkus. (2007). Beggar Communication Management, In Communication Research Methods: Examples of Qualitative Research with a Practical Approach. Bandung: Teenage Workshop

[11] _ (2009). Phenomenology Research Methodology, Bandung: WidyaPajajaran.

[12] Lubis, Mochtar. (1998). Police Imagery. Jakarta: Indonesian Torch Foundation.

[13] Moleong, Lexy J. (2007). Qualitative Research Methodology, Revised Edition, Bandung. PT. Teen Rosdakarya. 
[14] _ (1989). Qualitative Research Methodology. Bandung: RemadjaRosdakarya.

[15] Mulyana, Deddy. (2001). Communication Studies An Introduction. Bandung: PT. Teen Rosdakarya

[16] _. (2008). Communication Research Methods: Examples of Qualitative Research with Practical Approaches. Bandung: Teen Rosdakarya.

[17] Mulyana, Deddy. (2006). Introduction to the Sociology of Communication. Jakarta: Prenada Media Group.

[18] Raharjo, Satjipto and Tabah, Anton.(1993). Police Actor and Thinker. Jakarta: PT GramediaUtama.

[19] Raharjo, Satjipto. (2002). Civil Police in Social Change in Indonesia. Jakarta: Kompas.

[20] Raho, Bernard. (2004). Sociology: An Introduction. Surabaya: Sylvia.

[21] Rachmat, Jalaluddin. (2008). Psychology of Communication. Bandung: PT. Teen Rosdakarya.

[22] Riduwan.(2004). Research Method. Jakarta: RinekaCipta.

[23] Ruslan, Rosady. (1994). Public Relations Practices and Solutions in Crisis Situations and Image Recovery. PT. Ghalia Indonesia, Jakarta.

[24] Schlenker, B. R. (1980). Impression management: The self-concept, social identity and interpersonal relations. Monterey, CA: Brooks / Cole

[25] Soehartono, Irawan. (1995). Social Research Methods. Bandung: PT RemajaRosdakarya

[26] Soekanto, Soejono. (1990). Sociology An Introduction. Jakarta: PT. Raja GrafindoPersada.

[27] Sugiyono (2006).Understanding Qualitative Research. Bandung: Alfabeta.

[28] Be brave, Anton. (1991). Stare at the Eyes of the Indonesian Police. Jakarta: PT GramediaPustakaUtama.

[29] Widodo, Suko. 2010. Anatomy and Development of Social Theory. Aditya Media Publishing.Poor.

\section{JOURNAL AND SCIENTIFIC WRITING}

[1] Alim, ChelseAmand (2014). Normalization of the Monica Stigma through the Instagram Account (@agnezmo) Journal of e -- Communication 1-10.

[2] Ariani, D. Wahyu. (2014). Effects of Impression Management on Organizational Citizenship Behavior: An Empirical Study. Business Journal of Theory and Implementation. Vol. V, No. 1, February 2014. Pg. 11-41.

[3] Bahri, AndiniNur. (2018). The Role of Interpersonal Communication in the Work Environment in Islamic Perspectives. Scientific Journal of Religious Sociology Study Program of Sociology of Religion Faculty of Social Sciences UIN SU Medan. Vol.1, No.1, June 2018. Pg. 128-142.

[4] Bolino, M. C., Kacmar, M. K., Turnley, W. H., \&Gilstrap, B. J. (2008). A Multilevel Review of Normalizing stigma Motives And Behaviors. Journal of Management.

[5] Davies, J. (2007). Display, Identity, And The Everyday: Self-Presentation Through Online Image Sharing. Journal of Cultural Politics Education, 28 (4), 549-564

[6] Dewisyahyada Tami Mutiya and Fahmi, M. Husen. (2018). Dramaturgy Life of Judges in the Bandung District Court (Dramaturgy of the Judge's Life in the Court of Bandung).Proceedings of Public Relations. ISSN: 2460-6510. Volume 4, No. 2, 2018 Pg. 469-476.

[7] Godfrey, D., Jones, E. E., \& Lord, C. G. (1986). Self-promotion is not ingratiating. Journal of Personality and Social Psychology, 50, 106-115

[8] Harbet, Parlin. (2018). Management of the stigma normalization and the implementation of the feminine behavior of male make-up artists.Jurnal Media Kom, Vol.VIII, No.2, December 2018. Pg. 58-63

[9] McCusker, K., \&Gunaydin, S. (2015). Research using qualitative, quantitative or mixed methods and choice based on the research. Perfusion. DOI: 10.1177 / 0267659114559116

[10] Ngatiya.(2012). Law Enforcement of the Police Professional Ethics Code against Polri Members Committing Criminal Acts (Case Study at Pontianak Police).Thesis. Medan: University of North Sumatra.

[11] Pramudita Rah Mukti. (2014). Beggar Strategies in Community Life in the City of Surabaya, On-line journal of the Sociology Community of FISIP Airlangga University Vol. 1 No. 1, January 2013. http://journal.unair.ac.id (accessed in Bandung on 10 April 2014).

[12] Pudjiastuti, Wahyuni and Fadhal, Soraya. (2012). Student Opinion Against the Image of the Police of the Republic of Indonesia (POLRI). Al-Azhar Indonesia Journal of Social Pranata Series, Vol. 1, No. 3, March 2012. Pg. 201-216

[13] Pujileksono, Sugeng. (2010). The Collapse of Prisons As a Total Institution. Article. Volume 13 Number 1 January - June 2010. Pg. 81-94.

[14] Purnamasari, R. Ira Isprafika. (2007). The role of the police public relations in improving the image of the police. Thesis.Faculty of Communication, MercuBuana University, Jakarta.

[15] Son, Gisky Andria. (2017) Impression Management by Beggars (Dramaturgy Descriptive Study of Beggars AroundJalanPermindo, Padang City) Scientific Magazine. Vol. 25 Issue 2 173-180. 
[16] Ramdhani, Dikdik and Wiwitan, Tresna. (2018). Citra RidwanKamilAmong Journalists (Case Study of Citra RidwanKamil on Social Media as the Mayor of Bandung among Journalists). Proceedings of Public Relations.Volume 4, No. 2, 2018. Pg. 761-767

[17] Rosenfeld, P., Giacalone, R. A., \&Tedeschi, J. T. (1983).Humor and impression management. Journal of Social Psychology, 130 (4), 495-500.

[18] Sofiawati, Miranti. (2017) "Dramaturgy Study Regarding Motivation and Busker Behavior in Running Life in the City of Bandung".Pasundan University, Bandung.

[19] Suneki, Sri and Haryono. (2012). The Dramaturgy Theory Paradigm Against Social Life. CIVIS Scientific Journal, Volume II, No. 2, July 2012. Pg. 1-13.

[20] Viswesvaran, Chockalingan; Ones, DenizeS .; and Hough, Leaetta M. (2001). Do Normalize stigmascale in Personality Inventories Predict Managerial Job Performance ratings ?.International. Journal of Selection and assessment, 9 (4): 277-289

[21] Wawin, Dionisius C. Uran. (2014). The Drama of the Life of Ladies Who Work at Mitra Cafe \& KTV Samarinda Partners.eJournal Sociology Concentration, Volume 2, Number 1, 2014. Pg. 1-19

\section{ONLINE ARTICLES}

[1] http://forikes-ejournal.com/index.php/SF Journal-Forikes Sound Health Research

[2] FER. (2016). Chief of Police Call Policemen Spearhead Promoter Program. https://www.beritasatu.com/ nasional/382282/kapolri-sebut-polwan-ujung-tombak-program-promoter. Accessed 11 October 2018.

[3] Kompas.com. (2009)."The Police Remain Bad in the Eyes of the Community", https://megapolitan. kompas.com/read/2009/07/01/22265746/polisi.permanent.bad.di.mata_masyarakatAccessed December 13, 2018.

[4] Maskun (2013).Police Professionalism. Downloaded from: http: //www.negarahukum. com / law / professionalism-polri.html. December 20, 2018.

[5] Sumandoyo, Arbi. (2017). "Bad Police in the Eyes of the Community", https://tirto.id/cmwM Accessed on October 16, 2018.

[6] Tempo.co. (2016).Ideal description of police in the future.Thursday, 15 September 2016 16:42 WIB. https://nasional.tempo.co/read/804483/ overview-ideal-police-in-the-future.Accessed October 15, 2018.

[7] Trilaksono, Medi D.A. (2015). The Role of Public Relations in Yogyakarta Special District Police in Public Communication Management. GadjahMada University. Downloaded from http://etd.repository. ugm.ac.id/17 October 2018.

[8] (http://www.kompasiana.com/mariahardayanto/jangan-beri-uang-padapengemis 550e11b8a33311b02dba 7f42). Accessed July 28, 2016

[9] http://www.iiste.org ISSN 2422-8451 An International Peer-reviewed Journal Vol.37, 2017 Journal of Marketing and Consumer Research.

[10] https://nasional.kompas.com/read/2016/08/18/18524141/faktor.yang.membel.krtrust.publik.rendah.adapt.p olisi.versi.jgeneral.tito

[11] https://www.kompasiana.com/adrian.su4/5518346aa333118007b66398/maaf-pak-polisi-kami-belum-bisatrusted-kalian

[12] https://ferli1982.wordpress.com/2018/08/02/why-should-promoter/

[13] https://www.kompasiana.com/agus_oloan/595ddf7643322f12843fcf02/membifest-revolution-mentalindonesia-dari-polisi-promoter

[14] https://www.rappler.com/indonesia/berita/163647-hasil-survei-transparency-international-indonesia-dprlembaga-terkorup

[15] https://news.detik.com/berita/d-4227042/survei-lsi-polisi-pengaian-dan-pns-instansi- most-ko

Citation: Tri Siswanti, et.al. "Normalization of Dream State Police Stigma". International Journal of Humanities Social Sciences and Education (IJHSSE), vol. 6, no.10, 2019, pp. 127-133. doi: http://dx.doi.org/10.20431/2349-0381.0610015.

Copyright: (C) 2019 Authors. This is an open-access article distributed under the terms of the Creative Commons Attribution License, which permits unrestricted use, distribution, and reproduction in any medium, provided the original author and source are credited. 